\title{
The Efficiency of Online Learning Environment for Implementing Project-Based Learning: Students' Perceptions
}

\author{
Atef Mohammad Abuhmaid ${ }^{1}$ \\ ${ }^{1}$ Curricula and Teaching Methods Dep, Hashemite University, Jordan \\ Correspondence: Curricula and Teaching Methods Dep, Hashemite University, Jordan. \\ Received: June 15, 2020 \\ Accepted: July 2, 2020 \\ Online Published: July 6, 2020 \\ doi:10.5430/ijhe.v9n5p76 \\ URL: https://doi.org/10.5430/ijhe.v9n5p76
}

\begin{abstract}
Project-based learning is gaining increasing popularity supported by research studies regarding its effectiveness for teaching and learning. In addition, the widespread of digital technologies and sudden disruptions to traditional in-person teaching have accelerated the adoption of online learning. The current study examined students' perceptions of the impact of online learning environment on project-based teaching method. Most universities worldwide have considered online learning encouraging their faculty to use online learning tools, and Hashemite University in Jordan is no exeption. 154 students studying Computers in Education course were selected during the first semester of the academic year 2019/2020 and were devided into two groups. The experimental group consisted of 75 students who studied the course online and 79 students in the control group who studied the course in a face-to-face mode. For the purpose of gathering data, a questionnaire was developed which consisted of 17 items and students' answers were on a four-point Likert scale: 4= strongly agree, 3= agree, 2= disagree, and 1= strongly disagree. Means, standard deviations, and One-Way ANOVA were used to analyze the data. The results of the study showed positive attitudes among students (both online and in-class) toward project-based learning. In addition, the results showed that in-class students had a stronger views of project based-learning than online learning students.
\end{abstract}

Keywords: online learning, project-based learning, teaching methods, educational trends, higher education, creative teaching

\section{Introduction}

There is a consensus, to a large extent, among researchers that traditional teaching approaches do not prepare students properly for the 21 st century. Students, beyond basic subject-area knowledge, need a set of skills which are often called "twenty-first century skills" which make teaching and learning more connected to the real world in the new era (Larmer, Mergendoller, \& Boss, 2015). Students need to find ways to navigate through learning activities and solve problems as the learning experience unfolds. Thus, in order to become effective 21 st century learners, students should develop, side by side the content, competencies and skills including critical thinking, problem solving, collaboration, and making presentations in order to move beyond simple content area knowledge and skills to tackle more complex issues (Binkley, Erstad, Herman, Raizen, Ripley, Miller-Ricci, \& Rumble, 2012; Larmer, Mergendoller, \& Boss, 2015; Piirto, 2011).

In the 21 st century students rely heavily on technology and they trust it. They spend excessive time on digital technologies weather browsing, searching, watching online videos, or even doing academic tasks and activities. It is common to hear from students that they cannot separate their daily lives from digital technologies (Grant, 2011). Therefore, if we ignore digital technology, we might be shutting a valuable gate for teaching and learning in the 21 st century.

\section{Theoretical Background}

Changes to students' daily lives have also affected their perceptions about teaching and learning making traditional approaches obsolete and disengaging to them. Students' interaction with digital media has fundamentally transformed their understanding of knowledge and learning as the excessive use of various kinds of digital media and devices, has made this generation habituated to being engaged with what they watch and interact with. Therefore, the emphasis has been on instructional approaches that emphasize active learning which takes into account students' needs (Roessingh \& Chambers, 2011) providing them with learning experiences that emphasize $21^{\text {st }}$ century skills they need. However, this requires a shift from a lecture-based to a more engaging, flexible, and student-centred approach in instruction (Peters, 
2017). Previous generations used to watch what is broadcasted on TV passively, however, the 21 st century generation choose what to watch and which part of it. This type of interaction with the digital media in students' daily lives has overshadowed what traditional education systems design and provide. When a learning experience or activity is designed without taking the concepts of interaction and engagement in mind, the learning experience or activity are more likely to be dull and disengaging. Therefore, student-centred instruction was found to positively relate to students' engagement (Talbert, Hofkens \& Wang (2019).

Technological advancements have opened valuable opportunities for teaching and learning. Content delivery and searching for information have been have been fundamentally transformed. Instructors at universities have a wide variety of digital channels to deliver course materials freeing them from the limitations of the textbook and the classroom. An increasing number of teachers are experimenting how to integrate digital tools in their teaching by utilizing social media networks (e.g. Facebook groups, Twitter, WhatsApp groups) and YouTube videos to enhance teaching and learning (Faucher, 2018). Teachers and students can rely on the internet to find valuable and abundant information making the role of the instructor in traditional teaching questionable.

Both teachers and students have also become more comfortable with digital tools and channels and they are keen to integrate them into teaching and learning. Accordingly, technology enhanced teaching models are increasingly adopted such as online learning, blended learning, and flipped learning trying to benefit from what digital technologies have to offer.

\subsection{Project-Based Learning}

Project-based learning approach has been supported by research-based theories. Constructivists believe that learning is a journey of discovering meaningful information as students create their own understanding from the learning experience based on what they already know, which is emphasized by project-based learning (Roessingh \& Chambers, 2011). Additionally, terms such as "authentic learning activity" and "hands-on learning" are common in the constructivist literature (Jumaat, Tasir, Halim, \& Ashar, 2017) and adopted by project-based learning. Therefore, as an active student-centred form of instruction, project-based learning has a strong connection with the constructivism (Kokotsaki, Menzies, \& Wiggins, 2016).

Furthermore, project-based learning is believed to have positive impact on students' motivation to learn (Larmer, Mergendoller, \& Boss, 2015). Chiang and Lee (2016) conducted a study to examine the effect of project-based curriculum on students' learning motivation, which revealed that project-based learning could enhance students' learning motivation, and facilitate their problem-solving ability. In addition, Moursund (1999) reported that project-based learning does not only enhance students' motivation to learn, but also it fosters their cognitive engagement, and when students are motivated and cognitively engaged, they are more likely to learn and remember better. In addition, teachers in project-based learning teach in a more satisfying way (Larmer, Mergendoller, \& Boss, 2015) allowing them to activate students' role in the learning process and to focus on higher order skills (Moursund, 1999).

Buck Institute of Education defines project-based learning as a teaching method (Larmer, 2016), while Tan and Chapman (2016) say it is an approach rather than a method or a process. In this approach, learning experiences are organized around a project that extends over an extended period as students gain knowledge and skills by investigating and responding to complex questions, problems, or challenges. Thus, learning takes place through inquiry-based, student-driven projects. The projects are complex tasks based on challenging questions or problems that involve students in designing, problem solving, and decision-making while working on the project. The approach also gives students the opportunity to work relatively autonomously over extended periods of time; and it concludes in realistic products or presentations (Stanley, 2012).

Project-based learning in its essence is not a new approach to learning. John Dewey was a major proponent for the fundamentals of project-based learning such as; student-driven work that was hands-on, experiential, and relevant to the students' lives as far back as 100 years ago. However, project-based learning seems to fit well with new standards that contain performance-based tasks in addition to just the memorization of facts and content such as Common Core and Next Generation Science Standards (NGSS), which assess tasks as well as content (Larmer, Mergendoller, \& Boss, 2015). In project-based learning, learners work in groups to solve problems that are realistic, curriculum-based, and usually interdisciplinary (Yeh, 2013). At the end of the project, students are required to present a public and discussable product, which may strengthen the authenticity of the project and can motivate students to learn, and making their learning visible. Thus, project-based learning provide a pathway to a more authentic education that prepares students for the 21 st Century world. 
However, it is relatively easy for new concepts to be misunderstood. For project-based learning, when badly implemented, it might become another educational fad. Therefore, Buck Institute for Education identified the following seven essential project design elements (Larmer, 2016) to help designing projects around learning goals: A challenging problem or question, sustained inquiry, authenticity, student voice and choice, reflection, critique and revision, and public product.

Traditionally, project-based learning is implemented in classrooms where teachers are present to guide, assist, and monitor students' performance and progress through the project. However, new teaching models that rely on digital technologies such as online learning, flipped learning, and blended learning, learning moves to online learning environment, partially or entirely. Thus, project-based learning can face a challenge by the fundamental role of teachers and the learning space which is not the classroom or the computer lab any more. In online learning model, the whole learning happens online where there is no face-to-face meetings with the teacher. In this case, monitoring students working on their projects can be very limited to progress reports or assignments.

\subsection{Online Learning}

With widespread and pervasiveness of digital technology, an increasing number of faculty at universities are considering moving some of their teaching online. Online learning has gained an increasing attention from teaching staff and educational institutions as it has the potential to provide convenient and effective solutions for some of current educational issues. Online learning can extend learning opportunities by helping instructors to effectively deal with large cohorts of students, curricular, pedagogical, and administrative issues (Blin \& Munro, 2008; Sanagavarapu, 2018; Selwyn, 2007). In addition, online learning is mentioned for its flexibility (Keengwe \& Kidd, 2010) as students can learn remotely. Moreover, the increasing disruptions to traditional on campus learning can make online learning an optimal choice. For instance, the outbreak of the Coronavirus (COVID-19) worldwide have made online learning a priority to a large number of educational institutions and countries worldwide in order to control the spread of the virus requiring students to learn from home (Quintana, 2020; Zubașcu, 2020). Therefore, instructors were enforced to shift their teaching model to quickly adapt to the disruption by adopting online teaching, and Hashemite University is no exception.

While traditional teaching relies heavily on face-to-face interactions between instructors and students, online learning replaces this by the interaction of students with online instructional materials and indirect communication with the instructor. The way in which students are given the information or skills being taught in traditional learning emphasizes students as merely receptors of knowledge delivered by the instructor, whereas in active and effective teaching approaches, such as problem-based learning, students are encouraged to discover for themselves (Stanley, 2012). Nevertheless, there is still a question about its efficiency for learning, which is the ultimate business of education (Blin \& Munro, 2008; Sanagavarapu, 2018). Thus, as quality in online learning has become a leitmotiv for educational policies, a slogan for practitioners and a huge demand for learners (Ehlers \& Pawlowski, 2006), the current study examines the implementation of project-based learning in online learning environment. As online teaching is gaining more ground in teaching practices worldwide, focusing on the efficiency of online teaching and learning is needed.

\section{Research Questions}

\subsection{Research Questions}

The current study examined the efficiency of online learning environment to adopt a project-based learning model without the face-to-face interaction with the instructor. Therefore, the following research questions were formulated:

- What are the perceptions of students on project-based teaching method?

- How online learning environment can impact project-based learning from students' point of view?

\section{Method}

\subsection{Participants}

A total of 154 students participated in the study who were enrolled in "computers in education" course at Hashemite University during the first semester of the academic year 2019/2020. The first was the experimental group which consisted of 75 students who were studying the course online. The second group was the control group which consisted of 79 students who were studying the course in a face-to-face mode (Table 1). 
Table 1. Numbers and percentages of students in online and in-class groups

\begin{tabular}{lll}
\hline Group & No. & $\%$ \\
\hline Online Group & 75 & 48.7 \\
In-class Group & 79 & 51.3 \\
Total & 154 & 100
\end{tabular}

The current research study was carried out to examine the impact of online learning environment on the implementation of project-based learning. The research design utilized a post-test-only design as an experimental group and a control group were compared on a post-test measure only (Best \& Kahn, 1986; Cohen, Manion, \& Morrison, 2003; Martella, Nelson, Morgan, \& Marchand-Martella, 2013).

\subsection{Research Instrument}

In order to gather data from participants to answer the research questions, a questionnaire was developed. To ensure validity of the questionnaire, experts in the fields of educational technology, curriculum and instruction, and assessment and evaluation were consulted. The questionnaire which was modified according to the comments and suggestions received by the experts which were mainly wording and rewriting. The final version of the questionnaire consisted of 17 items and students were asked to answer on a four-point Likert scale: $4=$ strongly agree, $3=$ agree, $2=$ disagree, and $1=$ strongly disagree. In order to test the reliability of the questionnaire, 10 students were selected and divided into two groups as part of a pilot study. The coefficient reliability for the questionnaire was (0.88) on Cronbach's alpha, which was believed to be suitable for the purposes of the current study.

\subsection{Procedures}

At the beginning of the semester, students in both groups were introduced to the concept of project-based learning approach. Thus, students' role in the projects was explained emphasizing the importance of having active role in their groups. The first task for all students was to choose a topic in the wide area of educational technology. Topics were discussed with the teacher for fine-tuning and clarifying issues related to requirements, marks and deadlines. After the approval of topics, students asked to start the process (research, information mapping, searching and selecting proper technology (software, websites, applications) for the production phase, time and resources management during the production, and submission). Students in both groups were asked to submit three progress reports during the semester documenting and reflecting on challenges and problems they face while working on projects. The first progress report was documenting their search and their initial ideas about the topic after doing a research and trying to collect information and sources for the project. After one month into the project, students were required to submit the second progress report documenting and reflecting on their progress. The reflection task was important for them in order to conceive challenges as building blocks they can build on. The third report was due at the end of the semester when students submit their projects which showcases their journey into the project.

During the semester, the lecturer was following and monitoring students' progress (both online and in-class) in order to provide assistance and guidance when needed.

\subsection{Data Analysis}

The data obtained were analyzed using IBM SPSS in order to calculate Means, standard deviations, and ANOVA.

\section{Results}

This study aimed at examining students' perceptions of the impact of online learning environment on project-based teaching method. This section presents findings from the data collected to answer the two research questions.

The first research question was "what are the perceptions of students on project-based teaching method?" in order to answer the question, means standard deviations and levels of students' responses are presented in table (2).

Table 2. Means, standard deviations, and ranks of students' perceptions of project-based learning $(\mathrm{N}=154)$

\begin{tabular}{|c|c|c|c|}
\hline No & Items & Mean & SD \\
\hline 1. & $\begin{array}{l}\text { The project improved my motivation to the university degree I am }{ }_{\text {High }} \\
\text { studying }\end{array}$ & 3.71 & .559 \\
\hline 2. & $\begin{array}{l}\text { Working on the project helped me to achieve the learning goals of the }{ }_{\text {High }} \\
\text { course }\end{array}$ & 3.55 & .677 \\
\hline
\end{tabular}


3. Working on the project improved my creativity

High $\quad 3.48 \quad .669$

4.

The project improved my motivation to the university degree I am studying

High 3.48

5. Working on the project improved my motivation to learn in the course

High $\quad 3.42 \quad .790$

6. I felt that finishing the project was important to me

High $\quad 3.42 \quad .739$

7. I encourage my colleagues to work on projects in their learning

High $\quad 3.42 \quad .739$

8. I am satisfied with the final product

High $\quad 3.40 \quad .680$

9. I learnt many new skills by working on the project

High $\quad 3.40 \quad .680$

10. The university infrastructure (Software and hardware) is adequate to implement project-based learning.

11. The assistance and supports you received from your instructor

High $\quad 3.27 \quad .732$

12. I will use the project-based learning in my future teaching

High $\quad 3.26 \quad .712$

13. I prefer project-based learning to be implemented in other courses

High $\quad 3.17 \quad .765$

14. I received good assistance and supports you from my group

Table (2) shows that the overall mean for students' responses on the questionnaire was high (3.36) with a standard deviation of $(0.715)$, so, students in both groups expressed high positive views of project-based learning. While all items scored high, the item "The project improved my motivation to the university degree I am studying" was the highest with a mean of (3.71) and (0.559) standard deviation. The least item was "I received good assistance and supports you from my group" with a mean of (2.81) and (0.854) standard deviation. In addition, improving students' creativity was well noted as the item "Working on the project improved my creativity' had a mean of (3.48) and (0.669) standard deviation. Students also indicated that they "learnt many new skills by working on the project" with a mean of (3.4) and (0.68) standard deviation.

The second research question stated, "How online learning environment can impact project-based learning from students' point of view?" In order to answer this question, means and standard deviations were used to determine differences between online and in-class groups and the results are presented in table (3).

Table 3. Means and standard deviations of online group and in-class group on the impact of online learning environment on the implementation of project-based learning

\begin{tabular}{llll}
\hline Group & $\mathrm{N}$ & Mean & Std. Deviation \\
\hline Online & 75 & 3.27 & 0.74 \\
In-class & 79 & 3.45 & 0.68 \\
Total & 154 & 3.36 & 0.72
\end{tabular}

Table (3) shows apparent differences in the means of online and in-class groups in their perceptions on the impact of online learning environment on the implementation of project-based learning. The table shows that in-class group had stronger views of project-based learning with a mean of (3.45) and a standard deviation of $(0.68)$ while online learning students had a mean of (3.27) and (0.74) standard deviation. In order to examine the significance of these differences, ANOVA test was carried out and presented in table (4).

Table 4. ANOVA test of differences between online and in-class learning students

\begin{tabular}{llllll}
\hline Group & Sum of Squares & df & Mean Square & F & Sig. \\
\hline Between Groups & 12.781 & 1 & 12.781 & 70.236 & .000 \\
Within Groups & 27.660 & 152 & .182 & & \\
Total & 40.442 & 153 & & & \\
\hline
\end{tabular}


Table (4) shows significant differences ( $\mathrm{p}=0.00, \mathrm{~F}=70.236)$ between students in both groups in their perceptions on the impact of online learning environment on the implementation of project-based learning. The differences show that the in-class students had a better learning experience of project-based learning than students in the online learning group so they had a better perceptions of project-based learning in online environment.

\section{Discussion}

The current study aimed to explore the impact of online learning environment on the implementation of project-based learning. This section discusses the findings of the study considering previous literature and practices.

The findings showed positive attitudes toward project-based learning in general. There was a clear indication that project-based learning can motivate students' to learn triggering their passion and persistence to work better on the project and to get it completed. This finding confirms findings from other studies such as Larmer, Mergendoller, and Boss (2015) and Chiang and Lee (2016) stressing the positive impact of project-based learning on students' motivation. Triggered students' motivation in project-based learning might be due to students' satisfaction as they work on topics they chose. This might have given them a sense of relatedness encouraging them to complete it. This also might point to teachers' crucial role as designers for learning experiences that consider students' satisfaction while working on academic tasks (Baeten, Dochy, \& Struyven, 2013; Ryan \& Deci, 2000). Additionally, the finding can be linked to project-based learning's potential to invest and utilize students' own smartphones in producing something they enjoy. Therefore, students might become more engaged in their learning and feel more responsible and in charge (Mazur, 2009).

Furthermore, students stressed their enjoyment of the challenge as the majority of them indicated that this was the first time for them to work on projects within project-based learning method. They enjoyed the challenge and they showed persistence to complete their projects and feeling a sense of satisfaction with the final product. This might refute what some lecturers and students claim that students prefer traditional teaching. Thus, we might claim that students would prefer challenging tasks when they are engaged and when the challenge is meaningful to them. Additionally, students may enjoy the challenge even when it require more work and extra effort as they still can feel the sense of achievement and progress in their learning. In addition, students pointed to their preference of working in groups as they learned more and that is despite some complaints from students about problems they experienced as they worked with other.

Students also acknowledged the magnitude of skills and knowledge they acquired as they worked on the project. They pointed that that it was a different learning experience and they enjoyed it as they learned many software in order to accomplish their goal, which is something they did not experience in other traditional courses they had studied.

As the results related to the second research question illustrated, project-based learning was favoured more by in-class students than online learning students. Therefore, despite the fact that online learning can help lecturers to effectively deal with teaching large cohorts of students in terms of curricular, pedagogical, and administrative issues (Blin \& Munro, 2008; Sanagavarapu, 2018). However, the in-class learning environment was projected in the current study as a better learning environment to foster project-based learning. Despite the fact that students can still interact online through various social media channels, it seems that the presence of students and real interaction in-class was more effective and can positively reflect on the progress and quality of projects undertaken by students.

\section{Conclusion}

Project-based learning is gaining increasing popularity for its potentials to improve education by giving students more responsibility of their learning and giving them an active role. In addition, students can make sense of their learning through project-based learning, as they are required to present "products" that shows their learning and efforts. As online learning is also spreading and many courses worldwide are being shifted from the in-class to the virtual world, it is legitimate to question the effectiveness and potentials of new learning modes and their ability to foster certain teaching strategies. As Hashemite University is eager to adopt new technologies and teaching approaches, this must be considered in light of each initiative. Online learning, is powerful in overcoming certain barriers in traditional learning, as well as having great potentials for both educational institutions, lecturers, and students, however, it also has its own limitations.

Students, both online and in-class, showed strong positive view of project-based learning. However, as the spread of new digital technologies and the disruption to traditional teaching are increasingly pushing for more adoption to online learning, the effectiveness of implementing teaching strategies in light of the fundamental shift is legitimate.

Therefore, research often pointed to mixing teaching approaches and methods in order to overcome each one's own limitations. In this case, it might be better to integrate both teaching modes (online and in-class) in the form of well-established teaching modes such as blended learning and flipped learning. 


\section{References}

Baeten, M., Dochy, F., \& Struyven, K. (2013). The effects of different learning environments on students' motivation for learning and their achievement. British Journal of Educational Psychology, 83(3), 484-501. https://doi.org/10.1111/j.2044-8279.2012.02076.x

Best, J. W., \& Kahn, J. V. (1986). Research in Education (5th ed.). New Jersey: Prentice-Hall.

Binkley, M., Erstad, O., Herman, J., Raizen, S., Ripley, M., Miller-Ricci, M., \& Rumble, M. (2012). Defining Twenty-First Century Skills. In P. Griffin, B. McGaw, \& E. Care (Eds.), Assessment and Teaching of 21 st Century Skills. London: Springer. https://doi.org/10.1007/978-94-007-2324-5_2

Blin, F. o., \& Munro, M. (2008). Why hasn't technology disrupted academics' teaching practices? Understanding resistance to change through the lens of activity theory. Computers \& Education, 50(2), 475-490. https://doi.org/10.1016/j.compedu.2007.09.017

Chiang, C. L., \& Lee, H. (2016). The Effect of Project-Based Learning on Learning Motivation and Problem-Solving Ability of Vocational High School Students. International Journal of Information and Education Technology, 6(9), 709-712. https://doi.org/10.7763/IJIET.2016.V6.779

Cohen, L., Manion, L., \& Morrison, K. (2003). Research Methods in Education (5th ed.). New York: RoutledgeFalmer.

Ehlers, U.-D., \& Pawlowski, K. M. (2006). Quality in a Europe of Diverse Systems and Shared Goals. In U.-D. Ehlers \& K. M. Pawlowski (Eds.), Handbook on Quality and Standardisation in E-Learning. Berlin: Springer. https://doi.org/10.1007/3-540-32788-6

Faucher, K. X. (2018). Social Capital Online: Alienation and Accumulation. University of Westminster Press. https://doi.org/10.16997/book16

Grant, L. (2011). 'I'm a completely different person at home': using digital technologies to connect learning between home and school. Journal of Computer Assisted Learning, 27(4), 292-302. https://doi.org/10.1111/j.1365-2729.2011.00433.x

Jumaat, N. F., Tasir, Z., Halim, N. D. A., \& Ashar, Z. M. (2017). Project-Based Learning from Constructivism Point of View. Advanced Science Letters, 23(8), 7904-7906. https://doi.org/10.1166/asl.2017.9605

Keengwe, J., \& Kidd, T. T. (2010). Towards Best Practices in Online Learning and Teaching in Higher Education. Journal of Online Learning and Teaching, 6(2). https://doi.org/10.1177/1365480216659733

Kokotsaki, D., Menzies, V., \& Wiggins, A. (2016). Project-based learning: A review of the literature. Improving Schools, 19(3), 267-277. https://doi.org/10.1177/1365480216659733

Larmer, J. (2016). It's a Project-Based World. Educational Leadership, 73(6), 66-70.

Larmer, J., Mergendoller, J., \& Boss, S. (2015). Setting The Standard for Project Based Learning. Alexandria, VA: ASCD.

Martella, R. C., Nelson, J. R., Morgan, R. L., \& Marchand-Martella, N. E. (2013). Understanding and Interpreting Educational Research. New York: The Guilford Press.

Mazur, E. (2009). Farewell, Lecture? SCIENCE Magazine, 323, 50-51. https://doi.org/10.1126/science.1168927

Moursund, D. (1999). Project-Based Learning Using Information Technology. Portland, Oregon: International Society for Technology in Education (ISTE).

Quintana, C. (2020). College closings: More than 100 colleges cancel in-person classes and move online. Retrieved Date, April 19, from https://www.usatoday.com/story/news/education/2020/03/11/coronavirus-college-closings-list-online-classes/50 $22256002 /$

Peters, E. E. (2017). Shifting to a Student-Centered Science Classroom: An Exploration of Teacher and Student Changes in Perceptions and Practices. Journal of Science Teacher Education, 21(3), 329-349. https://doi.org/10.1007/s10972-009-9178-z

Piirto, J. (2011). Creativity for 21 st Century Skills: How to Embed Creativity into the Curriculum Rotterdam: Sense Publishers. https://doi.org/10.1007/978-94-6091-463-8 
Roessingh, H., \& Chambers, W. (2011). Project-Based Learning and Pedagogy in Teacher Preparation: Staking Out the Theoretical Mid-Ground. International Journal of Teaching and Learning in Higher Education, 23(1), 60-71.

Ryan, R. M., \& Deci, E. L. (2000). Self-determination theory and the facilitation of intrinsic motivation, social development, and well-being. American Psychologist, 55(1), 68-78. https://doi.org/10.1037/0003-066X.55.1.68

Sanagavarapu, P. (2018). From Pedagogue to Technogogue: A Journey into Flipped Classrooms in Higher Education. International Journal on E-Learning, 17(3), 377-399.

Selwyn, N. (2007). The use of computer technology in university teaching and learning: a critical perspective. Journal of Computer Assisted Learning, 23(2), 83-42. https://doi.org/10.1111/j.1365-2729.2006.00204.x

Stanley, T. (2012). Project-based learning for gifted students: A handbook for the 21stcentury classroom. Waco, Texas: Prufrock Press.

Talbert, E., Hofkens, T., \& Wang, M.-T. (2019). Does student-centered instruction engage students differently? The moderation effect of student ethnicity. The Journal of Educational Research, 112(3), 327-341. https://doi.org/10.1080/00220671.2018.1519690

Tan, J. C. L., \& Chapman, A. (2016). Project-Based Learning for Academically-Able Students. Rotterdam: Sense Publishers. https://doi.org/10.1007/978-94-6300-732-0

Yeh, H. (2013). The Making of Adult Learners through Project-Based Learning. In V. C. X. Wang (Ed.), Handbook of Research on Teaching and Learning in K-20 Education, 399-415. New York: IGI Global. https://doi.org/10.4018/978-1-4666-4249-2.ch023

Zubașcu, F. (2020). Mass closure of universities to prevent spread of COVID-19 in Europe. Retrieved Date Accessed, April 19, 2020 from https://sciencebusiness.net/news/mass-closure-universities-prevent-spread-covid-19-europe 